\title{
FERTILITY AND DEVELOPMENTAL TOXICITY STUDIES OF DIETHYLENE GLYCOL MONOBUTYL ETHER (DGBE) IN RATS
}

\author{
KRYSTYNA SITAREK, JOLANTA GROMADZIŃSKA, PIOTR LUTZ, JAN STETKIEWICZ, \\ RADOSŁAW ŚWIERCZ, and WOJCIECH WĄSOWICZ
}

Nofer Institute of Occupational Medicine, Łódź, Poland

Department of Toxicology and Carcinogenesis

\begin{abstract}
Objectives: The solvent, dimethylene glycol monobutyl ether (DGBE), is a component of latex paints, inks; it is used as a degreasing agent, industrial detergent. The aim of the study was evaluating the effects of DGBE administered by gavage on the estrous cycle and given with drinking water on fertility in rats and early development of their progeny. Materials and Methods: Female rats were exposed to DGBE by gavage during 8 weeks at 250,500 or $1000 \mathrm{mg} / \mathrm{kg} / \mathrm{day}$. Vaginal smears were collected during the exposure and 4 weeks after its cessation. Fertility studies were performed in male and female animals exposed to in drinking water. Males were exposed for 10 weeks and then mated with females exposed before mating, during pregnancy and lactation. Young animals were observed during 3 weeks after birth. Results: DGBE does not cause disturbances of the menstrual cycle in females. Parameters used to assess the general toxicity indicate that males receiving DGBE in drinking water are more sensitive to this compound than females: significantly greater, dose-dependent relative spleen weight, significant decrease in hematological parameters from $8 \%$ to $15 \%$ depending on the dose, were observed. Clinical chemistry parameters (HDL-cholesterol, BUN) and some markers of oxidative stress differ between the exposed groups and the control one, but without adverse health effect. The microscopic examination of internal organs did not reveal morphological changes in male and female rats. Conclusion: The results of our study on the impact of exposure to DGBE on fertility in rats indicate that the substance administered for 9-10 weeks to females and males at a limit dose of $1000 \mathrm{mg} / \mathrm{kg}$ did not impair fertility or viability of their offspring during the first three weeks of life.
\end{abstract}

Key words:

Dimethylene glycol monobutyl ether (DGBE), CAS No. 112-34-5, Female and male rats, Fertility

\section{INTRODUCTION}

Dimethylene glycol monobutyl ether (DGBE) is one of the glycol ethers which are widely used as chemical solvents. Some compounds of this group (ethylene glycol methyl ether, ethylene glycol methyl ether, their acetates and ethylene glycol dimethyl ether) are gonadotoxic, causing fertility disorders, birth defects and impaired development of animal offspring [1-6].
Dimethylene glycol monobutyl ether (DGBE) is a component of latex paints, inks, used as a degreasing agent, and industrial detergent [7,8]. DGBE belongs to harmful substances; LD50 per os for rats is $5100 \mathrm{mg} / \mathrm{kg}$ [8]. Because of its solubility in polar and nonpolar solvents, DGBE easily penetrates biological membranes. This substance is well absorbed through the respiratory tract, the gastrointestinal tract and the skin [9]. The

This study was supported by the Nofer Institute of Occupational Medicine scientific research program, project 1.9. "Assessment of estrous cycle of females, gonadotoxicity of males, biochemical and hematological parameters in rats after oral administration of dimethylene glycol monobutyl ether". The program manager: Krystyna Sitarek, PhD.

Received: July 4, 2012. Accepted: September 6, 2012.

Address reprint request to K. Sitarek, Department of Toxicology and Carcinogenesis, Nofer Institute of Occupational Medicine, św. Teresy 8, 91-348 Łódź, Poland (e-mail: ksitarek@imp.lodz.pl). 
major route of excretion of this substance and/or its metabolites is renal [10]. Data on the metabolism of DGBE are very scarce. DGBE metabolized to butoxyacetic acid in rat liver showed profound hemolytic effect on rat erythrocytes [11]. The mechanism of DGBE interaction with cells is not clear, possibly involving generation of oxidative stress during hepatic detoxification [12].

Under conditions of repeated exposure, DGBE is nephrotoxic, causing intravascular hemolysis $[8,13]$. Rats treated with DGBE in drinking water for 13 weeks showed slight hepatocyte hypertrophy and minor pathological changes in the kidneys. In addition, a modest reduction in the hematocrit value, concentration of $\mathrm{Hb}$ and erythrocyte count was noted. The authors concluded that these changes were adaptive in character [14].

DGBE is not mutagenic or genotoxic [15]. No embryotoxic or fetotoxic effects were noted in mice receiving the substance during organogenesis or in rats receiving it throughout the pregnancy $[16,17]$.

This study was intended to evaluate the effects of DGBE, given orally on the estrous cycle in female rats, and administered with drinking water on the fertility of male and female rats.

\section{MATERIAL AND METHODS}

The present study was performed in conformity with the current Polish and EU regulations (Official Gazette No. 11 of August 21, 1997, item 727, Act on Protection of Animals, Section 9: Experimental Procedures with the Use of Animals). The research team obtained the consent to proceed with the tests of animals from the Biomedical Ethics Committee, Łódź (Documents No. 18/ŁB355/2007 of February19, 2007).

\section{Chemical}

Diethylene glycol monobutyl ether (DGBE), CAS No. 112-34-5 of purity $\geq 98.0 \%$ (GC), LOT SZB93020, was obtained from Sigma-Aldrich Chemistry. The test substance used in this study was kept in a sealed container in a cool $\left(2-5^{\circ} \mathrm{C}\right)$ and dark place.

\section{Animals, living conditions and treatment}

Adult virgin female and male rats of the Wistar strain were obtained from our own breeding colony. The males and females were acclimated to the laboratory for 7 days prior to the start of the each experiment. The rats in good health were selected for study. The animals were housed in plastic cages containing sterile paddy husk as bedding material with controlled temperature $22 \pm 2^{\circ} \mathrm{C}$, light/dark cycle 12:12 h (light on at 6:00 a.m.), and relative humidity of 45-55\%. They were provided with commercial pellet diet (Fodder Factory, Motycz, Poland) ad libitum.

The animals were exposed to DGBE by gavage (estrous cycle) or in drinking water (reproductive toxicity). The stability of solutions of DGBE which were administered to the animals was verified by chromatography before and once a week during the study. All formulations were within $\pm 3 \%$ of the nominal concentrations and stable for at least 20 days at room temperature.

\section{Estrous cyclicity}

Sixty sexually mature female rats with regular 4-day estrous cycle were selected, randomly assigned to four groups, placed 2-3 per cage, with unlimited access to food and water, and used for testing the estrous cycle. The age of females on the day of starting the treatment was 11-12 weeks. The rats were each assigned a unique number prior to the start of the experiment. Females were exposed by gavage to solutions of DGBE in daily doses of 250,500 and $1000 \mathrm{mg} / \mathrm{kg}$ body weight $(5 \%, 10 \%$, and $20 \%$ LD 50 per os). DGBE was administered by gavage in the morning 5 days a week, for 8 weeks (volume of solutions $-0.5 \mathrm{ml}$ per $100 \mathrm{~g}$ body weight). The animals in the control group received by gavage the water used to prepare the solutions of DGBE, in the volume 
proportional to their body weight. Vaginal smears were taken every morning (8:00-9:00 a.m.), for 12 days, after 2 and 6 weeks of exposure and 4 weeks after the cessation of the exposure. Microscopic specimens were prepared and stained with hematoxylin and Shorr's stain. On the basis of the cytological image, four phases of the estrous cycle were distinguished [18]. The time of the estrous cycle's duration was assumed to be the period starting on the date on which the estrous phase was diagnosed in the vaginal smear and ending on the date on which the proestrous phase was observed. The mortality, body weight gain, feed and water intake of all the females was monitored during the exposure period and after cessation of the exposure.

\section{Reproductive toxicity and general toxicity of DGBE}

One hundred thirty-two male and female rats were used for this part of our study. Prior to the start of the experiment each animal was assigned a unique number. The animals were assigned to the following groups:

- study of fertility - control and exposed to DGBE at $1000 \mathrm{mg} / \mathrm{kg}$ (20 males and 20 females per each group),

- additional groups of animals for biochemical and pathological examinations - 8 females/group exposed to DGBE at doses 0, 250, 500 and $1000 \mathrm{mg} / \mathrm{kg}$ and 10 males/group receiving DGBE at 250 and $500 \mathrm{mg} / \mathrm{kg}$.

This experiment is a modification of the one-generation reproduction toxicity study [19]. Eighty female and male rats were randomly assigned as parental animals F0. The males at the age of 9 weeks were administered for 10 weeks ( 9 weeks before mating and 1 week during mating with females) solutions of DGBE in drinking water at a daily dose equivalent to $1000 \mathrm{mg} / \mathrm{kg}$ b.w. Animals in the control group received drinking water.

Female rats at the age of 10-11 weeks were exposed to DGBE at $1000 \mathrm{mg} / \mathrm{kg} /$ day 3 weeks prior to mating with males, as well as during pregnancy and lactation (the total of 9 weeks). The concentrations of the test substance were calculated from the values of the body weight of male or female rats and the daily intake of water monitored continuously during the experiment. The measurements of the body weight and intakes of the solutions were performed once a week. Throughout the experiment, regular observations of the health status of animals, their appearance and behavior were continued and their body weight, weight gain, daily food and water intake were also monitored.

After 9 weeks of exposure, males were mated with virgin, sexually mature females (1:1) from the same group of exposure and the same pairs of animals. The control animals were mated in the same way. The presence of sperm in vagina or a vaginal plug on the next morning was assumed to be the gestation day 0 (GD 0). Inseminated females weaned in individual single cages.

Pregnant females were checked every morning and the day on which the pups were first observed was assumed to be the postnatal day 1 (PND 1). On the 1st postnatal day (PND 1), the live and dead pups were counted, weighted and their gender was determined. On PND 4 the litters were culled to eight animals each and balanced for gender (4 females and 4 males) to the extent possible.

\section{Biochemical, hematological and pathomorphological examination}

Males from the control and DGBE-exposed (1000 mg/ $\mathrm{kg}$ ) groups were sectioned after mating. Females and males from additional groups exposed to DGBE at 250,500 and $1000 \mathrm{mg} / \mathrm{kg}$ in drinking water were sectioned after 9 or 10 weeks of exposure, respectively. Blood samples for biochemical tests were collected at 7:30-9:30 a.m. to minimize the differences arising from the circadian cycle. Before blood sampling, the animals were left without food at 5:00-6:00 p.m. on the day preceding the tests. Blood was collected by intracardiac puncture into two S-Monovette systems containing EDTA or lithium heparin as anticoagulant. 
S-Monovette tubes containing EDTA were used for all hematological determinations. Lithium heparin tubes were centrifuged (10 $\mathrm{min} 5000 \mathrm{rpm} / \mathrm{min}$ ), plasma was collected, erythrocytes were washed three times with $0.9 \% \mathrm{NaCl}$ and lysed by freeze-thawing. The following parameters were determined in the plasma to assess the overall health: concentration of total protein, creatinine, blood urea nitrogen (BUN), uric acid, total cholesterol and HDL-related fractions, triglycerides and activity of alanine aminotransferase (ALT) and aspartate aminotransferase (AST). Determinations of biochemical parameters in serum were performed using kits supplied by Alpha-DIAGNOSTICS (Poland). Precision and repeatability of the method were checked using the reference normal and pathological sera from the same company.

Markers of oxidative stress were measured in plasma (glutathione peroxidase activity (GSH-Px), thiobarbituric acid reactive substances (TBARS), ceruloplasmin activity (Cp), hemolysates (GSH-Px), superoxide dismutase activity (SOD) and liver and testis homogenates (GSH-Px, SOD, TBARS). In lysates of erythrocytes, hemoglobin was determined by the cyanmethhemoglobin method with Drabkin reagent. Liver and testis were homogenized in buffered physiological saline $\mathrm{pH} 7.4$ containing $5 \mathrm{mg} / \mathrm{l}$ EDTA (20\% w/vol.). The homogenate was centrifuged at $1000 \mathrm{rpm} / \mathrm{min}$ for $5 \mathrm{~min}$. Parts of the supernatant were used to determine TBARS. In cytosolic fraction, after centrifugation ( $80000 \times \mathrm{g}$ for $60 \mathrm{~min})$, GSH-Px and SOD activities were determined. The GSH-Px activity was determined by the method of Paglia and Valentine [20] with t-butyl hydroperoxide as the substrate.

Superoxide dismutase activity (SOD) in red blood cells and tissue homogenates was assayed with the use of the method based on the inhibition of reduction of nitroblue tetrasolium in the presence of xanthine and xanthine oxidase [21].

Cp oxidase activity in serum was determined using the spectrophotometry method by Sunderman and Nomoto [22].
The concentrations of TBARS were determined in serum and tissue homogenates using the method optimized by Wąsowicz et al. [23].

Internal organs were dissected and weighed (brain, liver, spleen, kidneys, adrenals, thyroid, pituitary gland and ovaries or testes and epididymis). The organs were fixed with $10 \%$ formalin in phosphate buffer. The tissues were prepared using routine paraffin technique. The 4 to $6 \mu \mathrm{m}$ paraffin sections were stained with hematoxylin and eosin in a Varistain Gemini Slide Stainer. Microscopic preparations were assessed qualitatively by light microscopy (Nikon Eclipse).

\section{Statistical analysis}

Absolute and relative weights of internal organs, hematological and biochemical parameters were compared using one-way analysis of variance followed by Dunnett's test. The frequency data (indices of fertility, viability, lactation, and developmental landmarks of pups) were analyzed using Fisher's exact probability test [24]. The effect on food and water consumption, body weight and body weight gain was evaluated by repeated measures analysis of variance [25]. In all statistical analyses, the difference between the compared variables was assumed to be statistically significant at $\mathrm{p}<0.05$. The data were subjected to analysis using STATA 9 package (Stata-Corp-LP, TX, USA).

\section{RESULTS}

\section{Estrous cycle}

In the control group and the groups exposed to DGBE at two intermediate doses there was no case of animal death, while the mortality of females in the highest dose group during the entire 14-week study period was $33.3 \%$ of the animals. Several females exposed to the test substance at the dose of $1000 \mathrm{mg} / \mathrm{kg}$ were in worse overall condition. Some of them were less active, had bristling hair, dyspnea, and blood around the nose and mouth. In total, the 
number of dead females was five: two females died in the third week of exposure, while one fatal case was recorded in each the fifth and eighth week of exposure and the first week post-exposure. The animals were examined for gross and microscopic lesions. Gross necropsy revealed dark liver in the rats. Microscopic examination revealed hyperkeratosis in forestomach in all of the dead females, while one of them, had also, pneumonia.

The general appearance and behavior of the females exposed to DGBE at 250 and $500 \mathrm{mg} / \mathrm{kg} /$ day did not differ from the behavior and appearance of the females in the control group. Observations of animals indicated that the body weight gain of the females receiving the lowest dose of DGBE $(250 \mathrm{mg} / \mathrm{kg})$ and their daily food and water intakes were similar to these in the control group. The body weight gains of the females exposed to the highest dose starting from 3rd week of exposure until the end of the observation, were statistically lower than in the control subjects. The body weight gain of the females from the $1000 \mathrm{mg}$ group during the exposure was by approximately $30 \%$ lower than in the controls. After the cessation of the exposure, the body weight gain of those females was still statistically lower. The body weight gain in the females given DGBE at the dose of $500 \mathrm{mg} / \mathrm{kg}$ was statistically lower only after the 7th week of exposure. The lower body weight gain was accompanied by decreased food consumption observed in the females from the two higher exposure groups. The daily water intake was similar in all groups of the females. A statistically significant difference was found only between the average daily water consumption in the control group and the group exposed to the highest dose of DGBE after 7 weeks of exposure. These results suggest that the dose of $1000 \mathrm{mg} / \mathrm{kg}$ (20\% LD50) was toxic to female rats (Table 1).

The average duration of the cycle, calculated from the estrous phase to the proestrous phase, was slightly longer

Table 1. Body weight gain, food and water consumption by the females receiving per os dimethylene glycol monobutyl ether

\begin{tabular}{|c|c|c|c|c|}
\hline \multirow{2}{*}{ Parameters } & \multicolumn{4}{|c|}{$\begin{array}{l}\text { Results }(\mathrm{M} \pm \mathrm{SD}) \\
\text { concerning administration of DGBE }\end{array}$} \\
\hline & $\begin{array}{l}\text { control } \\
(\mathrm{N}=15)\end{array}$ & $\begin{array}{c}250 \mathrm{mg} / \mathrm{kg} \text { b.w. } \\
(\mathrm{N}=15)\end{array}$ & $\begin{array}{c}500 \mathrm{mg} / \mathrm{kg} \text { b.w. } \\
(\mathrm{N}=15)\end{array}$ & $\begin{array}{c}1000 \mathrm{mg} / \mathrm{kg} \text { b.w } \\
(\mathrm{N}=10)\end{array}$ \\
\hline Initial body weight $(\mathrm{g})$ & $194.7 \pm 6.00$ & $194.7 \pm 7.00$ & $195.4 \pm 4.60$ & $198.0 \pm 9.80$ \\
\hline \multicolumn{5}{|l|}{ Body weight gain (g) } \\
\hline 3 weeks of exposure & $24.4 \pm 2.56$ & $21.9 \pm 2.79$ & $21.4 \pm 4.20$ & $16.6 \pm 3.81^{*}$ \\
\hline 7 weeks of exposure & $46.4 \pm 7.25$ & $44.4 \pm 4.22$ & $38.2 \pm 5.57^{*}$ & $30.7 \pm 9.85^{*}$ \\
\hline 5 weeks after the cessation of the exposure & $56.3 \pm 8.63$ & $55.0 \pm 5.79$ & $50.6 \pm 4.40$ & $44.7 \pm 10.21^{*}$ \\
\hline \multicolumn{5}{|l|}{ Daily food intake (g/rat) } \\
\hline 3 weeks of exposure & $17.0 \pm 1.06$ & $16.7 \pm 0.93$ & $14.9 \pm 0.41^{*}$ & $14.6 \pm 0.84^{*}$ \\
\hline 7 weeks of exposure & $17.6 \pm 0.65$ & $17.1 \pm 1.68$ & $15.7 \pm 0.99^{*}$ & $14.0 \pm 1.08^{*}$ \\
\hline 5 weeks after the cessation of the exposure & $19.4 \pm 0.91$ & $18.7 \pm 1.32$ & $18.2 \pm 1.34$ & $15.9 \pm 1.57^{*}$ \\
\hline \multicolumn{5}{|l|}{ Daily water intake (ml/rat) } \\
\hline 3 weeks of exposure & $30.4 \pm 3.87$ & $32.3 \pm 4.47$ & $31.2 \pm 4.80$ & $25.3 \pm 6.07$ \\
\hline 7 weeks of exposure & $28.6 \pm 7.28$ & $32.0 \pm 3.34$ & $30.3 \pm 4.37$ & $36.6 \pm 5.04^{*}$ \\
\hline 5 weeks after the cessation of the exposure & $32.8 \pm 6.32$ & $34.8 \pm 8.13$ & $34.9 \pm 2.47$ & $30.7 \pm 3.50$ \\
\hline
\end{tabular}

$\mathrm{M}$-mean, SD - standard deviation.

* Significantly different from the average in the control group $(\mathrm{p}<0.05)$. 
during 7-8th week of the exposure in the $500 \mathrm{mg} / \mathrm{kg}$ group, than in the controls $(5.55 \pm 2.97$ vs. $4.18 \pm 0.53$, respectively), but before the exposure it equaled in all groups from 4.1 to 4.2 days. This difference did not depend on the magnitude of exposure and was not statistically significant because of the large individual variability in this group.

\section{Reproductive toxicity and general toxicity of DGBE}

The animals were housed individually in cages and received ad libitum standard food and tap water with or without the test material. After 6 days of exposure, one female was removed from the experiment, because the animal developed an ear infection. The body weight, the weight gain, and the food and water consumption were monitored throughout the duration of the experiment. The body weight and body weight gain during gestation and lactation of the females and the body weight and body weight gain of the males were similar in the exposed and the control groups. No differences were noted either between the groups of animals of the same sex in the daily intake of food and water. The only significant difference was in the daily intake of water on the 20th day of gestation in the DGBE-treated group, which was significantly lower than in the control subjects. This difference seems to be rather accidental, because neither the body weight of the mothers nor the weight of their pups changed significantly compared to the controls. The body weight gain of the males during the exposure to DGBE at the highest dose was also lower than in other groups, however, the terminal body weights in all groups were similar.

All inseminated females gave birth to and raised offspring. The results of the study on the impact of exposure to DGBE on fertility in rats indicate that the test substance administered for 9-10 weeks to females and males did not impair their fertility or the viability of their offspring during the first three weeks of life. There were no significant differences between the groups in the number of pups per litter, male/female ratio, or the number of

Table 2. Effect of dimethylene glycol monobutyl ether on gestation and the reproductive performance of rats and the viability of their offspring

\begin{tabular}{|c|c|c|c|c|}
\hline \multirow[t]{2}{*}{ Parameters } & \multicolumn{4}{|c|}{$\begin{array}{c}\text { Results } \\
\text { concerning administration of DGBE }\end{array}$} \\
\hline & \multicolumn{2}{|c|}{ control } & \multicolumn{2}{|c|}{$1000 \mathrm{mg} / \mathrm{kg}$ b.w. } \\
\hline \multicolumn{5}{|l|}{ Females (n) } \\
\hline inseminated & \multicolumn{2}{|c|}{20} & \multicolumn{2}{|c|}{19} \\
\hline pregnant & \multicolumn{2}{|c|}{19} & \multicolumn{2}{|c|}{18} \\
\hline Pups (n) & females & males & females & males \\
\hline born alive & 68 & 71 & 68 & 65 \\
\hline born dead & 0 & 0 & 0 & 3 \\
\hline pups that survived up to 4 days & 65 & 68 & 68 & 63 \\
\hline pups that survived up to 21 days & 65 & 68 & 68 & 63 \\
\hline \multicolumn{5}{|l|}{ Index $(\%)$} \\
\hline $\begin{array}{l}\text { fertility (inseminated females that became } \\
\text { pregnant) }\end{array}$ & \multicolumn{2}{|c|}{95.0} & \multicolumn{2}{|c|}{94.7} \\
\hline viability (born alive that survived to 4 days) & \multicolumn{2}{|c|}{95.7} & \multicolumn{2}{|c|}{97.8} \\
\hline $\begin{array}{l}\text { lactation (pups alive after } 4 \text { days that } \\
\text { survived up to } 21 \text { days) }\end{array}$ & \multicolumn{2}{|c|}{100.0} & \multicolumn{2}{|c|}{100.0} \\
\hline
\end{tabular}


stillbirths. The indices of fertility $(\%$ of inseminated females that got pregnant), viability ( $\%$ of pups born alive that survived up to 4 days) and lactation (\% of pups alive after 4 days that survived up to 21 days) have similarly high values, near $100 \%$, both in the control group and in the group exposed to DGBE at $1000 \mathrm{mg} / \mathrm{kg}$. Body weight of offspring born in the control group did not significantly differ from the body weight of offspring born in the group exposed to DGBE at a dose of $1000 \mathrm{mg} / \mathrm{kg}$ (Table 2 and 3). The males were sectioned after 10 weeks, and females after 9 weeks of exposure. Several percent higher than in the control group were the relative spleen weights of all exposed males. Lower than in the controls was absolute kidneys weight in males exposed to the two intermediate doses, while the relative kidneys weight in the $1000 \mathrm{mg} / \mathrm{kg}$ group was by $20 \%$ higher. Also, the absolute pituitary weight was lower in the highest exposure group. No changes, essential from the toxicological point of view, were observed in sectioned males in absolute and relative weight of the testis, epididymis, brain, liver, adrenals or thyroid (Table 4).

Higher than in the female controls was the absolute weight of the spleen and pituitary of the females in 250 and $500 \mathrm{mg} / \mathrm{kg}$ groups and the kidney weight in the $250 \mathrm{mg} / \mathrm{kg}$ group. Absolute thyroid weight

Table 3. Physical development of the pups concerning mothers administration of dimethylene glycol monobutyl ether

\begin{tabular}{lcccc}
\hline & \multicolumn{3}{c}{$\begin{array}{c}\text { Body weight of offspring (g) (M per litter } \pm \text { SD }) \\
\text { concerning mothers administration of DGBE }\end{array}$} \\
\cline { 2 - 5 } & Postnatal day & \multicolumn{2}{c}{ control } & \multicolumn{2}{c}{$1000 \mathrm{mg} / \mathrm{kg}$ b.w. } \\
\cline { 2 - 5 } & pups females & pups males & pups females & pups males \\
\hline 1st & $5.6 \pm 0.5$ & $6.0 \pm 0.8$ & $5.5 \pm 0.9$ & $5.8 \pm 0.8$ \\
9th & $13.8 \pm 1.4$ & $14.5 \pm 2.0$ & $12.6 \pm 1.3$ & $13.3 \pm 1.7$ \\
21st & $32.2 \pm 2.9$ & $33.8 \pm 2.8$ & $30.2 \pm 2.5$ & $31.7 \pm 3.0$ \\
\hline
\end{tabular}

Abbreviations as in Table 1.

Table 4. Absolute and relative organ weight in the male rats receiving dimethylene glycol monobutyl ether in drinking water

\begin{tabular}{|c|c|c|c|c|}
\hline \multirow{2}{*}{ Parameters } & \multicolumn{4}{|c|}{$\begin{array}{c}\text { Results }(\mathrm{M} \pm \mathrm{SD}) \\
\text { concerning administration of DGBE }\end{array}$} \\
\hline & $\begin{array}{l}\text { control } \\
(\mathrm{N}=20)\end{array}$ & $\begin{array}{c}250 \mathrm{mg} / \mathrm{kg} \text { b.w. } \\
(\mathrm{N}=10)\end{array}$ & $\begin{array}{c}500 \mathrm{mg} / \mathrm{kg} \text { b.w. } \\
(\mathrm{N}=10)\end{array}$ & $\begin{array}{c}1000 \mathrm{mg} / \mathrm{kg} \text { b.w. } \\
(\mathrm{N}=20)\end{array}$ \\
\hline $\begin{array}{c}\text { Testis }(\mathrm{g}) \\
(\mathrm{g} \%)\end{array}$ & $\begin{array}{l}3.17 \pm 0.06 \\
0.77 \pm 0.01\end{array}$ & $\begin{array}{l}3.15 \pm 0.05 \\
0.86 \pm 0.02\end{array}$ & $\begin{array}{l}2.94 \pm 0.14 \\
0.78 \pm 0.04\end{array}$ & $\begin{array}{l}3.15 \pm 0.03 \\
0.85 \pm 0.02\end{array}$ \\
\hline $\begin{array}{l}\text { Epididymis }(\mathrm{g}) \\
\quad(\mathrm{g} \%)\end{array}$ & $\begin{array}{l}0.60 \pm 0.01 \\
0.14 \pm 0.002\end{array}$ & $\begin{array}{l}0.55 \pm 0.01 \\
0.15 \pm 0.003\end{array}$ & $\begin{array}{l}0.52 \pm 0.02 \\
0.13 \pm 0.007\end{array}$ & $\begin{array}{l}0.56 \pm 0.01 \\
0.15 \pm 0.006\end{array}$ \\
\hline $\begin{array}{l}\text { Brain }(\mathrm{g}) \\
\quad(\mathrm{g} \%)\end{array}$ & $\begin{array}{l}1.87 \pm 0.03 \\
0.45 \pm 0.01\end{array}$ & $\begin{array}{l}1.82 \pm 0.03 \\
0.50 \pm 0.01\end{array}$ & $\begin{array}{l}1.82 \pm 0.03 \\
0.48 \pm 0.01\end{array}$ & $\begin{array}{l}1.81 \pm 0.01 \\
0.48 \pm 0.01\end{array}$ \\
\hline $\begin{array}{l}\text { Liver }(\mathrm{g}) \\
\quad(\mathrm{g} \%)\end{array}$ & $\begin{array}{r}14.47 \pm 0.37 \\
3.51 \pm 0.07\end{array}$ & $\begin{array}{r}13.62 \pm 0.50 \\
3.72 \pm 0.06\end{array}$ & $\begin{array}{r}13.78 \pm 0.60 \\
3.63 \pm 0.06\end{array}$ & $\begin{array}{r}13.79 \pm 0.52 \\
3.70 \pm 0.09\end{array}$ \\
\hline $\begin{array}{l}\text { Spleen }(\mathrm{g}) \\
(\mathrm{g} \%)\end{array}$ & $\begin{array}{l}0.64 \pm 0.03 \\
0.15 \pm 0.005\end{array}$ & $\begin{array}{l}0.61 \pm 0.02 \\
0.17 \pm 0.006\end{array}$ & $\begin{array}{l}0.68 \pm 0.03 \\
0.18 \pm 0.007^{*}\end{array}$ & $\begin{array}{l}0.68 \pm 0.02 \\
0.18 \pm 0.006^{*}\end{array}$ \\
\hline $\begin{array}{l}\text { Kidneys }(\mathrm{g}) \\
\quad(\mathrm{g} \%)\end{array}$ & $\begin{array}{l}2.75 \pm 0.06 \\
0.67 \pm 0.02\end{array}$ & $\begin{array}{l}2.42 \pm 0.08^{*} \\
0.66 \pm 0.02\end{array}$ & $\begin{array}{l}2.47 \pm 0.06^{*} \\
0.65 \pm 0.01\end{array}$ & $\begin{array}{l}2.81 \pm 0.07 \\
0.75 \pm 0.01 *\end{array}$ \\
\hline
\end{tabular}


Table 4. Absolute and relative organ weight in the male rats receiving dimethylene glycol monobutyl ether in drinking water - cont.

\begin{tabular}{|c|c|c|c|c|}
\hline \multirow{2}{*}{ Parameters } & \multicolumn{4}{|c|}{$\begin{array}{c}\text { Results }(\mathrm{M} \pm \mathrm{SD}) \\
\text { concerning administration of DGBE }\end{array}$} \\
\hline & $\begin{array}{c}\text { control } \\
(\mathrm{N}=20)\end{array}$ & $\begin{array}{c}250 \mathrm{mg} / \mathrm{kg} \text { b.w. } \\
(\mathrm{N}=10)\end{array}$ & $\begin{array}{l}500 \mathrm{mg} / \mathrm{kg} \text { b.w. } \\
(\mathrm{N}=10)\end{array}$ & $\begin{array}{c}1000 \mathrm{mg} / \mathrm{kg} \text { b.w. } \\
(\mathrm{N}=20)\end{array}$ \\
\hline $\begin{array}{l}\text { Adrenals (mg) } \\
(\mathrm{mg} \%)\end{array}$ & $\begin{array}{l}46.31 \pm 2.21 \\
11.31 \pm 0.62\end{array}$ & $\begin{array}{l}40.97 \pm 1.94 \\
11.26 \pm 0.50\end{array}$ & $\begin{array}{l}42.73 \pm 1.66 \\
11.35 \pm 0.46\end{array}$ & $\begin{array}{l}45.26 \pm 1.39 \\
12.20 \pm 0.47\end{array}$ \\
\hline $\begin{array}{l}\text { Thyroid (mg) } \\
\text { (mg\%) }\end{array}$ & $\begin{array}{r}15.48 \pm 0.92 \\
3.77 \pm 0.24\end{array}$ & $\begin{array}{r}13.51 \pm 0.77 \\
3.72 \pm 0.22\end{array}$ & $\begin{array}{r}14.40 \pm 0.63 \\
3.82 \pm 0.18\end{array}$ & $\begin{array}{r}14.54 \pm 0.62 \\
3.91 \pm 0.14\end{array}$ \\
\hline $\begin{array}{l}\text { Pituitary (mg) } \\
\quad(\mathrm{mg} \%)\end{array}$ & $\begin{array}{r}21.90 \pm 2.45 \\
5.44 \pm 0.72\end{array}$ & $\begin{array}{r}22.14 \pm 2.25 \\
6.22 \pm 0.78\end{array}$ & $\begin{array}{r}23.16 \pm 1.45 \\
6.15 \pm 0.40\end{array}$ & $\begin{array}{c}18.46 \pm 1.40^{*} \\
3.93 \pm 0.37\end{array}$ \\
\hline Terminal body weight (g) & $360.80 \pm 7.46$ & $362.75 \pm 7.01$ & $377.35 \pm 8.68$ & $351.95 \pm 7.61$ \\
\hline
\end{tabular}

Abbreviations as in Table 1.

$\mathrm{g} \%$ or $\mathrm{mg} \%$ - relative organ weight ( $\mathrm{g}$ or $\mathrm{mg} / 100 \mathrm{~g}$ b.w.).

Table 5. Absolute and relative organ weight in the female rats receiving dimethylene glycol monobutyl ether in drinking water

\begin{tabular}{|c|c|c|c|c|}
\hline \multirow{2}{*}{ Parameters } & \multicolumn{4}{|c|}{$\begin{array}{c}\text { Results }(\mathrm{M} \pm \mathrm{SD}) \\
\text { concerning administration of } \mathrm{DGBE}\end{array}$} \\
\hline & $\begin{array}{l}\text { control } \\
(\mathrm{N}=8)\end{array}$ & $\begin{array}{l}250 \mathrm{mg} / \mathrm{kg} \text { b.w. } \\
\quad(\mathrm{N}=8)\end{array}$ & $\begin{array}{l}500 \mathrm{mg} / \mathrm{kg} \text { b.w. } \\
\quad(\mathrm{N}=8)\end{array}$ & $\begin{array}{c}1000 \mathrm{mg} / \mathrm{kg} \text { b.w. } \\
\quad(\mathrm{N}=8)\end{array}$ \\
\hline $\begin{array}{l}\text { Ovaries (mg) } \\
(\mathrm{mg} \%)\end{array}$ & $\begin{array}{l}87.44 \pm 12.60 \\
36.37 \pm 5.21\end{array}$ & $\begin{array}{l}81.96 \pm 16.19 \\
30.60 \pm 4.89\end{array}$ & $\begin{array}{l}76.79 \pm 13.20 \\
31.23 \pm 5.90\end{array}$ & $\begin{array}{l}81.68 \pm 10.44 \\
31.89 \pm 4.23\end{array}$ \\
\hline $\begin{array}{l}\text { Brain }(\mathrm{g}) \\
\quad(\mathrm{g} \%)\end{array}$ & $\begin{array}{l}1.77 \pm 0.10 \\
0.74 \pm 0.03\end{array}$ & $\begin{array}{l}1.81 \pm 0.14 \\
0.68 \pm 0.06\end{array}$ & $\begin{array}{l}1.85 \pm 0.05 \\
0.75 \pm 0.04\end{array}$ & $\begin{array}{l}1.84 \pm 0.08 \\
0.72 \pm 0.08\end{array}$ \\
\hline $\begin{array}{l}\text { Liver }(\mathrm{g}) \\
\quad(\mathrm{g} \%)\end{array}$ & $\begin{array}{l}8.85 \pm 0.86 \\
3.67 \pm 0.26\end{array}$ & $\begin{array}{r}10.90 \pm 1.67 \\
4.09 \pm 0.51\end{array}$ & $\begin{array}{r}9.86 \pm 1.07 \\
4.00 \pm 0.43\end{array}$ & $\begin{array}{l}9.88 \pm 1.48 \\
3.88 \pm 0.72\end{array}$ \\
\hline $\begin{array}{l}\text { Spleen }(\mathrm{g}) \\
(\mathrm{g} \%)\end{array}$ & $\begin{array}{l}0.50 \pm 0.05 \\
0.21 \pm 0.02\end{array}$ & $\begin{array}{l}0.59 \pm 0.07^{*} \\
0.22 \pm 0.02\end{array}$ & $\begin{array}{l}0.61 \pm 0.10^{\mathrm{b}} \\
0.25 \pm 0.05\end{array}$ & $\begin{array}{l}0.56 \pm 0.07 \\
0.22 \pm 0.03\end{array}$ \\
\hline $\begin{array}{l}\text { Kidneys }(\mathrm{g}) \\
\quad(\mathrm{g} \%)\end{array}$ & $\begin{array}{l}1.54 \pm 0.09 \\
0.64 \pm 0.03\end{array}$ & $\begin{array}{l}1.77 \pm 0.09^{*} \\
0.67 \pm 0.04\end{array}$ & $\begin{array}{l}1.71 \pm 0.25 \\
0.69 \pm 0.09\end{array}$ & $\begin{array}{l}1.67 \pm 0.21 \\
0.66 \pm 0.13\end{array}$ \\
\hline $\begin{array}{l}\text { Adrenals (mg) } \\
\quad(\mathrm{mg} \%)\end{array}$ & $\begin{array}{l}67.98 \pm 7.86 \\
28.19 \pm 2.44\end{array}$ & $\begin{array}{l}70.14 \pm 6.30 \\
26.34 \pm 2.11\end{array}$ & $\begin{array}{l}64.75 \pm 7.68 \\
26.20 \pm 2.23\end{array}$ & $\begin{array}{l}61.13 \pm 3.99 \\
23.96 \pm 3.02 *\end{array}$ \\
\hline $\begin{array}{l}\text { Thyroid (mg) } \\
\text { (mg\%) }\end{array}$ & $\begin{array}{r}13.49 \pm 1.80 \\
5.60 \pm 0.66\end{array}$ & $\begin{array}{c}14.40 \pm 1.46^{*} \\
5.41 \pm 0.47\end{array}$ & $\begin{array}{c}12.43 \pm 1.57^{*} \\
5.03 \pm 0.50\end{array}$ & $\begin{array}{c}11.73 \pm 1.70^{*} \\
4.61 \pm 0.90\end{array}$ \\
\hline $\begin{array}{c}\text { Pituitary (mg) } \\
(\mathrm{mg} \%)\end{array}$ & $\begin{array}{r}11.49 \pm 1.94 \\
4.76 \pm 0.71\end{array}$ & $\begin{array}{c}15.16 \pm 2.80^{*} \\
5.71 \pm 1.16\end{array}$ & $\begin{array}{c}14.85 \pm 2.23^{*} \\
6.04 \pm 1.02\end{array}$ & $\begin{array}{c}13.49 \pm 1.43 \\
5.28 \pm 0.73^{*}\end{array}$ \\
\hline Terminal body weight (g) & $240.75 \pm 12.40$ & $266.63 \pm 18.02$ & $246.88 \pm 16.83$ & $257.88 \pm 30.33$ \\
\hline
\end{tabular}

Abbreviations as in Table 1 and 4.

in the $250 \mathrm{mg} / \mathrm{kg}$ group was greater, but in the 500 and $1000 \mathrm{mg} / \mathrm{kg}$ ones it was lower than in the control females. In the $1000 \mathrm{mg} / \mathrm{kg}$ females, the relative weight of adrenals was lower, and as regards the pituitary it was significantly higher. The absolute and/or relative weight of other organs (ovaries, brain, and liver) of the females exposed to DGBE was similar to the weight of the respective organs of the control females (Table 5). 
Table 6. Hematological parameters in the male rats receiving dimethylene glycol monobutyl ether in drinking water

\begin{tabular}{lcccc}
\hline \multirow{2}{*}{\multicolumn{1}{c}{ Parameters }} & \multicolumn{3}{c}{ Results $(\mathrm{M} \pm \mathrm{SD})$} \\
& concerning administration of DGBE \\
\cline { 2 - 5 } & $(\mathrm{N}=10)$ & $250 \mathrm{mg} / \mathrm{kg}$ b.w. & $500 \mathrm{mg} / \mathrm{kg}$ b.w. & $1000 \mathrm{mg} / \mathrm{kg}$ b.w. \\
& $44.40 \pm 1.50$ & $40.80 \pm 1.90^{*}$ & $41.20 \pm 2.00^{*}$ & $38.70 \pm 3.10^{*}$ \\
\hline Hematocrit $(\%)$ & $15.90 \pm 0.60$ & $14.50 \pm 0.70^{*}$ & $14.60 \pm 0.60^{*}$ & $13.40 \pm 1.30^{*}$ \\
Hemoglobin $(\mathrm{g} / \mathrm{dl})$ & $9.01 \pm 0.50$ & $8.34 \pm 0.40^{*}$ & $8.37 \pm 0.30^{*}$ & $7.75 \pm 0.80^{*}$ \\
Red blood cells $\left(\times 10^{6} / \mathrm{mm}^{3}\right)$ & $6.34 \pm 1.24$ & $5.85 \pm 1.65$ & $5.65 \pm 2.51$ & $5.00 \pm 1.80$ \\
White blood cells $\left(\times 10^{3} / \mathrm{mm}^{3}\right)$ & $45.10 \pm 1.40$ & $51.0 \pm 4.40^{*}$ & $49.2 \pm 6.80^{*}$ & $50.20 \pm 8.70^{*}$ \\
Lymphocytes $(\%)$ & & & & \\
\hline
\end{tabular}

Abbreviations as in Table 1.

Table 7. Hematological parameters in the female rats receiving dimethylene glycol monobutyl ether in drinking water

\begin{tabular}{|c|c|c|c|c|}
\hline \multirow{2}{*}{ Parameters } & \multicolumn{4}{|c|}{$\begin{array}{c}\text { Results }(\mathrm{M} \pm \mathrm{SD}) \\
\text { concerning administration of DGBE }\end{array}$} \\
\hline & $\begin{array}{l}\text { control } \\
(\mathrm{N}=8)\end{array}$ & $\begin{array}{l}250 \mathrm{mg} / \mathrm{kg} \text { b.w. } \\
\quad(\mathrm{N}=8)\end{array}$ & $\begin{array}{l}500 \mathrm{mg} / \mathrm{kg} \text { b.w. } \\
\quad(\mathrm{N}=8)\end{array}$ & $\begin{array}{c}1000 \mathrm{mg} / \mathrm{kg} \text { b.w } \\
(\mathrm{N}=8)\end{array}$ \\
\hline Hematocrit (\%) & $39.60 \pm 2.00$ & $40.30 \pm 2.30$ & $39.20 \pm 6.20$ & $40.80 \pm 1.50$ \\
\hline Hemoglobin (g/dl) & $13.80 \pm 0.70$ & $14.10 \pm 0.80$ & $13.30 \pm 2.20$ & $14.10 \pm 0.60$ \\
\hline Red blood cells $\left(10^{6} / \mathrm{mm}^{3}\right)$ & $7.96 \pm 0.38$ & $7.99 \pm 0.46$ & $7.29 \pm 1.06$ & $8.04 \pm 0.34$ \\
\hline White blood cells $\left(10^{3} / \mathrm{mm}^{3}\right)$ & $5.93 \pm 2.36$ & $4.95 \pm 1.29$ & $4.75 \pm 2.15$ & $4.38 \pm 1.58$ \\
\hline Lymphocytes (\%) & $55.90 \pm 3.60$ & $53.00 \pm 3.00$ & $54.00 \pm 6.80$ & $55.90 \pm 2.80$ \\
\hline
\end{tabular}

Abbreviations as in Table 1.

\section{Hematological and biochemical analysis}

Hematological parameters (hematocrit, Hb level, RBC count) were significantly lower in all groups of the male rats receiving DGBE in drinking water as compared with the controls. In the female rats receiving DGBE in drinking water these parameters did not differ compared with the controls. The percentage of lymphocytes in blood of the exposed males was significantly higher vs. the controls, but the difference was not related to the daily dose of DGBE (Table 6 and 7).

A statistically significant increase in the plasma BUN levels was noted in the males exposed to DGBE in drinking water at 250 and $1000 \mathrm{mg} / \mathrm{kg}$. The HDL fraction of plasma cholesterol was significantly lower in the male rats exposed to 500 and $1000 \mathrm{mg} / \mathrm{kg}$ DGBE as compared with the non-exposed animals (Table 8 and 9). No changes were observed in the concentration of the total protein, creatinine, uric acid, total cholesterol, triglycerides and activity of alanine aminotransferase, glutamine aminotransferase between the rats receiving DGBE and the controls (data not shown).

Among plasma oxidative stress markers, significant differences were recorded only in all the exposed males. Cp activities in the exposed groups were almost $100 \%$ higher than in the controls. Cp activities in the control rat females were nearly $50 \%$ higher than in the control males.

The liver SOD activity was significantly lower in the females exposed to 500 and $1000 \mathrm{mg} / \mathrm{kg}$ DGBE in drinking water as compared with the controls. In the exposed males, the liver SOD activity did not differ between the exposed groups and the controls. The TBARS level in the liver 
Table 8. Biochemical parameters in the male rats receiving dimethylene glycol monobutyl ether in drinking water

\begin{tabular}{|c|c|c|c|c|}
\hline \multirow{2}{*}{ Parameters } & \multicolumn{4}{|c|}{$\begin{array}{c}\text { Results }(\mathrm{M} \pm \mathrm{SD}) \\
\text { concerning administration of DGBE }\end{array}$} \\
\hline & $\begin{array}{l}\text { control } \\
(\mathrm{N}=10)\end{array}$ & $\begin{array}{l}250 \mathrm{mg} / \mathrm{kg} \text { b.w. } \\
\quad(\mathrm{N}=10)\end{array}$ & $\begin{array}{l}500 \mathrm{mg} / \mathrm{kg} \text { b.w. } \\
\quad(\mathrm{N}=10)\end{array}$ & $\begin{array}{c}1000 \mathrm{mg} / \mathrm{kg} \text { b.w. } \\
\quad(\mathrm{N}=10)\end{array}$ \\
\hline Ceruloplasmin, plasma (g/l) & $0.37 \pm 0.11$ & $0.76 \pm 0.23^{*}$ & $0.63 \pm 0.29^{*}$ & $0.82 \pm 0.25^{*}$ \\
\hline BUN, plasma (mg/dl) & $18.00 \pm 3.50$ & $21.50 \pm 1.5^{*}$ & $20.10 \pm 2.1$ & $21.30 \pm 1.6^{*}$ \\
\hline HDL cholesterol, plasma (mg/dl) & $48.30 \pm 11.38$ & $40.20 \pm 7.99$ & $36.40 \pm 9.20^{*}$ & $36.10 \pm 7.20^{*}$ \\
\hline TBARS, liver (nmol/mg protein) & $17.00 \pm 2.62$ & $18.80 \pm 1.25$ & $21.00 \pm 3.28^{*}$ & $18.30 \pm 3.93$ \\
\hline 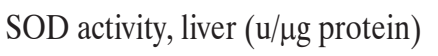 & $5.20 \pm 0.23$ & $5.20 \pm 0.39$ & $5.30 \pm 0.52$ & $5.20 \pm 0.46$ \\
\hline TBARS, testis (nmol/mg protein) & $17.80 \pm 2.97$ & $23.50 \pm 6.52 *$ & $25.00 \pm 4.84^{*}$ & $23.70 \pm 4.54^{*}$ \\
\hline
\end{tabular}

Abbreviations as in Table 1.

Table 9. Biochemical parameters in the female rats receiving dimethylene glycol monobutyl ether in drinking water

\begin{tabular}{|c|c|c|c|c|}
\hline \multirow{2}{*}{ Parameters } & \multicolumn{4}{|c|}{$\begin{array}{c}\text { Results }(\mathrm{M} \pm \mathrm{SD}) \\
\text { concerning administration of DGBE }\end{array}$} \\
\hline & $\begin{array}{l}\text { control } \\
(\mathrm{N}=8) \\
\end{array}$ & $\begin{array}{c}250 \mathrm{mg} / \mathrm{kg} \text { b.w. } \\
(\mathrm{N}=8)\end{array}$ & $\begin{array}{c}500 \mathrm{mg} / \mathrm{kg} \text { b.w. } \\
(\mathrm{N}=8)\end{array}$ & $\begin{array}{c}1000 \mathrm{mg} / \mathrm{kg} \text { b.w } \\
(\mathrm{N}=8)\end{array}$ \\
\hline Ceruloplasmin, plasma (g/l) & $0.55 \pm 0.09$ & $0.60 \pm 0.05$ & $0.53 \pm 0.10$ & $0.54 \pm 0.08$ \\
\hline BUN, plasma (mg/dl) & $16.50 \pm 4.50$ & $17.30 \pm 2.30$ & $18.20 \pm 2.80$ & $17.70 \pm 3.10$ \\
\hline HDL cholesterol, plasma (mg/dl) & $44.60 \pm 7.27$ & $60.50 \pm 22.20$ & $48.90 \pm 10.90$ & $47.90 \pm 10.20$ \\
\hline TBARS, liver, (nmol/mg protein) & $29.20 \pm 6.41$ & $29.20 \pm 4.76$ & $26.60 \pm 1.84$ & $25.80 \pm 2.57$ \\
\hline SOD activity, liver ( $\mathrm{u} / \mu \mathrm{g}$ protein) & $6.60 \pm 0.36$ & $6.20 \pm 0.51$ & $5.50 \pm 0.78^{*}$ & $4.70 \pm 0.83^{*}$ \\
\hline
\end{tabular}

Abbreviations as in Table 1.

homogenate of the males receiving DGBE at $500 \mathrm{mg} / \mathrm{kg}$ was significantly higher than in the controls, and the testis TBARS level was significantly higher in all groups receiving the chemical (Table 8 and 9).

No significant changes were observed in the GSH-Px activity in all analyzed tissues (results not included in the tables).

\section{Pathomorphological examinations}

The morphology seminiferous epithelium and the spermatogenesis process of all rats exposed to DGBE were within the normal limits. Bulks of spermatozoa were observed in the lumen of ducts epididymidis. Minimal granulocyte infiltrations were observed in prostate glands of 5/20 rats exposed to DGBE at $1000 \mathrm{mg} / \mathrm{kg}$ and of 2/10 controls. The incidence of these findings was not statistically significant ( $p=0.57$ ). DGBE at the doses $250-1000 \mathrm{mg} / \mathrm{kg}$, given to male rats does not induce pathological changes in the spermatoferous epithelium and spermatogenesis process. The microscopic examination of epididymides, seminal vesicles, prostate, pituitary gland, thyroid gland, liver, kidneys, spleen and urinary bladder did not reveal morphological changes in the rats exposed to DGBE with drinking water in comparison with the control subjects. The pathomorphological assessment of the female organs showed, only in the $1000 \mathrm{mg} / \mathrm{kg}$ group, cell proliferation in the spleen red pulp and the partial disappearance of the lymph nodules. No changes were observed in other organs of the females exposed to DGBE at 250, 500 and $1000 \mathrm{mg} / \mathrm{kg}$ for 9 weeks. 


\section{DISCUSSION}

Among the doses used in first part of the study, when DGBE was administered by gavage, only the highest of them was evidently toxic to the females, which was manifested by increased mortality, slower body weight gain and reduced daily food intake persisting even after the exposure. Certain effects of DGBE toxicity could also be observed in the females from the $500 \mathrm{mg} / \mathrm{kg}$ group, but they seemed to be reversible. Although DGBE administered by gavage to the females at the dose $1000 \mathrm{mg} / \mathrm{kg}$ proved to be toxic to them, it did not induce significant disturbances in the estrous cycle during or after exposure.

There was no case of death among the 19 females and 20 males given DGBE at $1000 \mathrm{mg} / \mathrm{kg}$ b.w. in drinking water. The fertility of adult rats, the number of pups born by the control and exposed females, and sex ratio in the offspring groups did not differ. The trend in the weight gain of the offspring of both sexes in the first three weeks of life was also similar in the control subjects and the DGBE groups. A detailed discussion of the results of our studies regarding the effect on fertility DGBE is impossible, due to lack of data in the literature closely related to the problem.

Only Nolen et al. [26] and Auletta et al. [27] studied the effect of this chemical on fertility. However, in the first of these studies, the exposed females mated with nonexposed males, or vice versa, and in the second one, the animals were exposed by dermal administration $6 \mathrm{~h} /$ day, 5 days/week for 13 weeks. Our study was conducted in accordance with the OECD 415 and animals of both sexes were exposed to DGBE by means of drinking water. The exposed females were mated with the exposed males, and the control females with the control males.

The results of our studies on fertility are in line with the observations of other authors. Auletta et al. [27] evaluated the fertility of rats exposed to DGBE by dermal route using occlusive exposure $6 \mathrm{~h} /$ day, 5 days/week for 13 weeks. To evaluate the general toxicity, $10 \%, 30 \%$ and undiluted DGBE preparations were applied, while only the highest dose of the substance was used in the reproduction study. As in our study, no impairment was noted in the estrous cycle or fertility of the females, or in the offspring development.

Similarly, Nolen et al. [26] noted no impairment of fertility in female rats exposed orally to DGBE at 0, 250, 500 and $1000 \mathrm{mg} / \mathrm{kg} 2$ weeks prior to mating, during gestation, until day 13 of lactation. The females were mated with non-treated males. Another group was composed of males exposed to the same doses for 60 days prior to mating, and then mated with non-exposed females. Abnormalities in fertility or offspring development were not observed in any of the groups. The only difference was lower mean weight of the pups delivered by the females receiving DGBE at $1000 \mathrm{mg} / \mathrm{kg}$ during the later stages of lactation.

The results of our observations indicate that DGBE reduces hematological parameters in male rats. Administration with drinking water of DGBE at $250 \mathrm{mg} / \mathrm{kg}$ to male rats decreased by about $8 \%$ hematocrit, $\mathrm{Hb}$ concentration and erythrocyte count, whereas the dose of $1000 \mathrm{mg} / \mathrm{kg}$ decreased $\mathrm{Hb}$ concentration by $16 \%$ and erythrocyte count by $14 \%$. These changes were not observed in the females. Similarly, in the EC report [28], a decrease in erythrocyte count, $\mathrm{Ht}$ and $\mathrm{Hb}$ levels were observed in F344 rats receiving DGBE at $250 \mathrm{mg} / \mathrm{kg}$ for 90 days [14]. Metabolic pathway of DGBE formed a small amount of butoxyacetic acid [29]. The studies on the metabolism of ethylene glycol butyl ether have shown that butoxyacetic acid is responsible for hemolysis. Rats' erythrocytes are very sensitive to hemolysis, and even low level of butoxyacetic acid decreases the RBC account and $\mathrm{Hb}$ level [11].

Clinical chemistry parameters were unaffected in the females receiving DGBE at the doses 250, 500 and $1000 \mathrm{mg} / \mathrm{kg}$. A significant decrease was observed in the plasma HDL fraction of cholesterol in the males receiving the two highest doses of the chemical $(36.4 \pm 9.20 \mathrm{mg} /$ $\mathrm{dl}$ and $36.1 \pm 7.20 \mathrm{mg} / \mathrm{dl}$ vs. $48.3 \pm 11.38 \mathrm{mg} / \mathrm{dl}$ in the 
controls, $p<0.05)$. Significant, ca. $20 \%$ increases in the BUN levels, were observed in the males receiving $250 \mathrm{mg} /$ $\mathrm{kg}$ and $1000 \mathrm{mg} / \mathrm{kg}$. These results are in conformity with the data obtained by Johnson et al. [14], who observed a slight, but significant decrease in the AST activity and total protein and cholesterol concentrations in both genders after administration of $1000 \mathrm{mg} / \mathrm{kg}$ for 13 weeks. The differences in these parameters after 2 weeks of administration were insignificant. After 13-week dermal application in the male and female rats, there were no differences in the clinical chemistry parameters either [27].

To assess the mechanism of interaction of DGBE with bioactive cell compounds, the makers of oxidative stress were analyzed. In the previously published studies on the health effects of glycol ethers, it had been found that a structurally similar compound, ethylene glycol n-butyl ether, may induce oxidative damage in the liver of male mice [30]. We found elevated levels of the markers of prooxidative processes - TBARS in the liver of male rats after administration of $500 \mathrm{mg} / \mathrm{kg}$ of DGBE and in the testis after all doses of the investigated compound.

Hepatic I Phase enzymes can produce active intermediates, which generate reactive oxygen species and slightly increase oxidative stress after the administration of $1000 \mathrm{mg} / \mathrm{kg}$. The activity of the mixed function oxidase was unchanged after the administration of DGBE, but the activities of other hepatic I Phase enzymes were slightly elevated [14]. An increase in the TBARS levels may result from the reaction of ROS generated during I Phase of detoxification with lipids. Increased TBARS levels were observed only in the liver of male rats after the administration of $500 \mathrm{mg} / \mathrm{kg}$. It should be considered whether the administration of high doses of this substance initiates other unknown protective mechanisms. In such a case the elimination of a part of DGBE would take place via other pathways. The decreased SOD activity in the liver of females receiving DGBE at the doses of 500 and $1000 \mathrm{mg} / \mathrm{kg}$ confirms the imbalance in the antioxidant-oxidant pathway. The decrease in the SOD activity equaled $17 \%$ in the group receiving $500 \mathrm{mg} / \mathrm{kg}$ and $29 \%$ in the group given $1000 \mathrm{mg} / \mathrm{kg}$ as compared with the controls. Some modulations in the oxidative stress markers were observed during this study. However, these results are unclear and certainly further studies are necessary.

\section{CONCLUSION}

Diethylene glycol monobutyl ether did not cause disturbances of the menstrual cycle in the female rats. DGBE administered for 9-10 weeks to the females and males at the limit dose of $1000 \mathrm{mg} / \mathrm{kg} /$ day did not impair the fertility or viability of their offspring during the first three weeks of life. The males receiving DGBE in drinking water were more sensitive to the toxic effects of this compound. A significant dose-dependent decrease was shown in the hematological parameters and clinical chemistry parameters (HDL-cholesterol, BUN) and some markers of oxidative stress differed in the exposed and control males, but without the negative health effects.

DGBE is a substance of low general toxicity and it does not impair the reproductive function, so there is no basis for the search of the mechanism of action of this substance. In the literature there are no data on the distribution of DGBE in the body. Given the hydrophilic nature of this substance (Kow $=0.56$ ), it can be assumed that its distribution is homogeneous in tissues rich in water. Therefore, it is unlikely to accumulate in the body and consequently, low systemic toxicity of DGBE after repeated administration can be assumed.

In spite of the above, the results of our study have some practical value. They can be used for regulatory purposes such as determining the maximum permissible concentrations in the environment, as well as classification of this substance taking into account its toxicity and proper labeling. 


\section{ACKNOWLEDGMENTS}

The authors wish to acknowledge Zdzisława Pisarek and Barbara Kołodziejczak for their excellent technical assistance during this study.

\section{REFERENCES}

1. Andrew FD, Hardin BD. Developmental effects after inhalation exposure of gravid rabbits and rats to ethylene glycol monoethyl ether. Environ Health Perspect 1984;57:13-23.

2. Stanger EG, Aeppli L, Muller D, Peheim E, Thomann P. The toxicology of ethylene glycol monoethylether. Arzneim Forsch 1971;21:880-5 [in German].

3. Hardin BD, Niemeier RW, Smith RJ, Kuczuk MH, Mathinos PR, Weaver TF. Teratogenicity of 2-ethoxyethanol by dermal application. Drug Chem Toxicol 1982;5(3):277-94.

4. Nelson BK, Setzer JV, Brightwell WS, Mathinos PR, Kuczuk MH, Weaver TE, et al. Comparative inhalation teratogenicity of four glycol ether solvents and an amino derivative in rats. Environ Health Perspect 1984;57:261-71.

5. Nagano K, Nakayama E, Oobayashi H, Yamada T, Adachi H, Nishizawa T, Ozawa, et al. Embryotoxic effects of ethylene glycol monomethyl ether in mice. Toxicology 1981;20(4): $335-43$.

6. Boatman RJ, Knaak JB. Ethers of ethylene glycol and derivatives. In: Bingham E, Cohrssen B, Powel CH, editors. Patty's Toxicology. Vol.7. 5th ed. Part D, chapter 86. NewYork: Wiley Interscience; 2001. p. 73-270.

7. Göen T, Korinth G, Drexler H. Butoxyethoxyacetic acid, a biomarker of exposure to water-based cleaning agents. Toxicol Lett 2002;134:295-300.

8. Gingell R, Boatman RA, Corley RA, Knaak JB, Rosica KA, Wise RC. Toxicology of diethylene glycol butyl ether. Occup Hyg 1996;2:293-302.

9. Barber E. Teetsel NM, Kolberg KF, Guest D. A comparative study of the rates of in vitro percutaneous absorption of eight chemicals using rat and human skin. Fundam Appl Toxicol 1992;19:493-7.
10. Deisinger PJ, Guest D. Metabolic studies with diethylene glycol monobutyl ether acetate (DGBA) in the rat. Xenobiotica 1989;19:981-9.

11. Udden MM. Effects of diethylene glycol butyl ether and butoxyethoxyacetic acid in rat and human erythrocytes. Toxicol Lett 2005;156:95-101.

12. Wells PG, Winn LM. Biochemical toxicology of chemical teratogenesis. Crit Rev Biochem Mol Biol 1996;31:1-40.

13. Hobson DW, Wyman JF, Lee LH, Bruner RH, Uddin DE. Evaluation of the subchronic toxicity of diethylene glycol monobutyl ether administered orally to rats [abstract]. Toxicologist 1986;6:659.

14. Johnson KA, Baker PC, Kan HL, Maurissen JP, Spencer PJ, Marty MS. Diethylene glycol monobutyl ether (DGBE): two and thirteen-week oral toxicity studies in Fisher 344 rats. Food Chem Toxicol 2005;43:467-81.

15. Gollapudi BB, LinscombeVA, McClintock ML, Sinha AK, Stack CR. Toxicology of diethylene glycol butyl ether 3. Genotoxicology evaluation in an in vitro gene mutation assay and an in vitro cytogenetic test. J Am Coll Toxicol 1993;12:155-9.

16. Schuler RL, Hardin BD, Niemeler RW, Booth G, Hazelden K, Vincent Piccirillo V, Smith K. Results of testing fifteen glycol ethers in a short-term in vivo reproductive toxicity assay. Environ Health Perspect 1984;57:141-6.

17. Ema M, Itami T, Kawasaki H. Teratology study of diethylene mono-n-butyl ether in rats. Drug Chem Toxicol 1988;11: 97-111.

18. Fox RR, Laird CW. Sexual cycles. In: Hafez ESE, editor. Reproduction and Breeding Techniques For Laboratory Animals. Philadelphia: Lea and Febiger; 1970. p. 107-21.

19. OECD. OECD guideline for testing of chemicals. Test No. 415: One-Generation Reproduction Toxicity Study; 1983.

20. Paglia DE, Valentine VW. Studies on the quantitative and qualitative characterization of erythrocyte glutathione peroxidase. J Lab Clin Med 1967;70:158-69.

21. Beauchamp C, Fridovich I. Superoxide dismutase: improved assays and an assay applicable gel. Anal Biochem 1971;44:276-87. 
22. Sunderman FW Jr., Nomoto S. Measurement of human serum ceruloplasmin by its p-phenylenediamine oxidase activity. Clin Chem 1970;16:903-10.

23. Wąsowicz W, Neve J, Peretz A. Optimized steps in fluorometric determination of thiobarbituric acid-reactive substances in serum: Importance of extraction $\mathrm{pH}$ and influence of sample preservation and storage. Clin Chem 1993;39:2522-6.

24. Zar JH. Biostatistical analysis. Englewood Cliffs, New York: Prentice-Hall, Inc.; 1974.

25. Fischer LD, Belle G. Biostatistics. A Methodology for the Health Sciences. New York: John Wiley and Sons; 1993.

26. Nolen GA, Gibson WB, Benedict JH, Briggs DW, Scardein JL. Fertility and teratogenic studies of diethylene glycol monobutyl ether in rats and rabbits. Fund Appl Toxicol 1985;5:1137-43.
27. Auletta CS, Schroeder RE, Krasavage WJ, Stack CR. Toxicology of diethylene glycol butyl ether. 4. Dermal subchronic/ reproduction study in rats. J Am Coll Toxicol 1993;12:161-8.

28. European Commission's Directorate-General for Health and Consumer Protection. Opinion on diethylene glycol monobutyl ether (DEGBE). SCCP/1043/06 [cited 9 Dec 2006]. Available from URL: http://ec.europa.eu/health/ph_risk/committees/04_sccp/docs/sccp_o_081.pdf.

29. Boatman RJ, Schum DB, Guest D, Stack CR. Toxicology of diethylene glycol butyl ether. 2. Disposition studies with 14C-diethylene glycol butyl ether and 14C-diethylene glycol butyl ether acetate after dermal application to rats. J Am Coll Toxicol 1993;12:145-54.

30. Siesky AM, Kamendulis LM, Klaunig JE. Hepatic effects of 2 butoxyethanol in rodents. Toxicol Sci 2002;70:252-60.

This work is available in Open Access model and licensed under a Creative Commons Attribution-NonCommercial 3.0 Poland License - http://creativecommons.org/ licenses/by-nc/3.0/pl/deed.en. 